\title{
Pengaruh Buah Kundur (Benincasa hispida) dan Buah Nanas (Ananas comosus L. Merr) Rasio Serta Konsentrasi Gula Terhadap Mutu Fruit Leather
}

\author{
Ruka Yulia $^{1^{*}}$, Noni Handayani ${ }^{2}$, Juliani $^{3}$ \\ ${ }^{1,2,3}$ Prodi Teknologi Pangan, Fakultas Teknologi Pertanian \\ Universitas Serambi Mekkah \\ *Koresponden email: ruka.yulia@gmail.com
}

Diterima: 8 Januari 2020

Disetujui: 3 Maret 2020

\begin{abstract}
Fruit leather is a flesh of fruit that has been crushed and dried at $50-60^{\circ} \mathrm{C}$. The study aimed to determine the effect of ratio of gourd and pineapple and the addition of sugar in the production of fruit leather. The variables were analyzed for chemistry analysis and organoleptic response. Chemical analyzes performed were water content analysis and fiber content. Organoleptic responses include color, aroma, texture, and flavor. The data was analyzed by Randomized Completely Design with two factorial. The ratio of kundur and pineapple (K) those are 80:20\%, 70:30\%, 60:40\% while (G) those are $20 \%, 30 \%$ and $40 \%$. The result of this study showed that the ratio of the concentration of kundur and pineapple 80:20\% while the concentration of sugar $30 \%\left(\mathrm{~K}_{1} \mathrm{G}_{2}\right)$ produced fruit leather of the highest quality with a moisture content of $8.15 \%$, fiber content of 1.882 , and organoleptic response of texture 3.80 (like), color 3,71 (like), aroma 3,58 (like), flavor 3,91 (like).
\end{abstract}

Keywords: Fruit Leather, sugar, kundur, pineapple, water content, fiber content, organoleptic

\begin{abstract}
Abstrak
Fruit leather merupakan daging buah yang telah dihancurkan dan dikeringkan pada $50-60^{\circ} \mathrm{C}$. Penelitian ini bertujuan untuk mengetahui pengaruh perbandingan buah kundur dan nanas dan penambahan gula pasir pada pembuatan fruit leather yang dihasilkan. Variabel dianalisis untuk analisa kimia dan uji organoleptik. Analisis kimia yang dilakukan adalah analisis kadar air dan kadar serat. Respons organoleptik meliputi warna, aroma, tekstur, dan rasa. Data dianalisis dengan Rancangan Acak Lengkap dengan dua faktorial. Rasio kundur dan nanas (K) yaitu 80: 20\%, 70: 30\%, 60: 40\% sementara (G) yaitu 20\%, 30\% dan 40\%. Hasil penelitian menunjukkan bahwa perbandingan konsentrasi buah kundur dan nanas 80:20\% dan konsentrasi gula 30\% $\left(\mathrm{K}_{1} \mathrm{G}_{2}\right)$ menghasilkan fruit leather dengan mutu terbaik dengan kadar air 8,15\%, kadar serat 1,882, dan uji organoleptik tekstur 3,80 (suka), warna 3,71 (suka), aroma 3,58 (suka), rasa 3,91 (suka).
\end{abstract}

Kata Kunci : Fruit Leather, gula, kundur, nanas, kandungan air, kandungan serat, organoleptik

\section{Pendahuluan}

Buah kundur (Benincasa hispida) merupakan salah satu kekayaan alam hayati yang banyak terdapat di Indonesia. Persebaran Benincasa hispida sangat melimpah di Indonesia karena mudah tumbuh di daerah tropis. Jenis buah ini termasuk dalam tanaman Cucurbitaeae yang sering dimanfaatkan sebagai obat herbal dan sayuran oleh masarakat. Komponen utama buah kundur adalah minyak atsiri, flavonoid, glikosida, sakarrida, protein, karoten, vitamin, mineral, $\beta$-sitosterin, dan asam uronat [1]. Buah kundur juga kaya akan kalium dengan kandungan sekitar 0,27 g/100 g. Selain itu, kandungan yang dimiliki buah kundur sangat baik bagi tubuh, seperti kandungan antioksidan yang tinggi yaitu 17,2 mg dan kandungan serat yang tinggi yang bermanfaat untuk pencernaan dan usus [2]. Melihat potensi buah kundur yang begitu banyak bagi kesehatan, maka penting untuk dilakukan pengolahan lebih lanjut untuk menghasilkan suatu produk yang menarik minat masyarakat.

Bentuk olahan buah kundur relatif masih sangat sedikit, padahal buah dari tanaman menjalar ini memiliki banyak khasiat. Buah kundur memiliki rasa agak langu, dalam pengolahannya sifat langu tersebut dapat diminimalisir dengan cara mencampurnya dengan buah lain yang memiliki aroma dan rasa sangat khas. Buah nanas (Ananas comosus L. Merr) merupakan buah yang tumbuh di daerah tropis yang memiliki sifat organoleptik yang kuat baik dari segi rasa dan aroma. Sifat tersebut berpotensi untuk 
menutupi kekurangan dari buah kundur dari segi rasa dan aroma. Salah satu bentuk olahan buah kundur yang dapat ditambahkan dengan buah nanas yaitu produk fruit leather.

Fruit leather adalah hasil dari produk olahan yang terbuat dari bubur buah yang dicampur bersama dengan bahan tambahan makanan seperti karbohidrat (glukosa, sorbitol, maltodekstrin, permen karet dan pektin) dan senyawa nutraceuticals (inulin, kalsium, vitamin) [3]. Bahan makanan tambahan akan memperbaiki dan menentukan sifat instrinsik kulit seperti rasa, tekstur, fleksibilitas, warna, dan viskositas. Berbagai buah tropis dengan kadar serat cukup tinggi dapat diolah menjadi fruit leather seperti sirsak, nangka, semangka, salak, pisang, nanas, papaya, mangga dan sebagainya.

Komposisi pendukung yang ditambahkan untuk menciptakan karakteristik fruit leather yaitu gula dan pektin. Menurut Ref. [4] kualitas fruit leather yang baik ditentukan oleh beberapa komponen utama yaitu kandungan gula, pektin, dan asam. Ketiga komponen tersebut akan berpengaruh terhadap lembaran fruit leather yang dihasilkan. Gula memberikan rasa manis yang khas pada fruit leather dan juga sebagai pengawet alami. Selanjutnya, penambahan pektin pada bubur buah dilakukan untuk menghasilkan karakteristik struktur fruit leather yang padat dan elastisitas yang baik sehingga dapat dengan mudah digulung, karena pada dasarnya pektin berperan sebagai bahan perekat/pengental (gelling agent) [5].

Penelitian sebelumnya dilakukan oleh Ref. [6] dengan menghasilkan produk olaham fruit leather (campuran mangga dan rosella) dengan karakteristik fisika dan kimia yang sesuai mutu dan disukai konsumen. Ref. [6] melaporkan bahwa formulasi perbandingan terbaik dan dapat diterima oleh panelis adalah $35 \%$ mangga $+25 \%$ rosella dan gula $40 \%$ dengan kadar air $14,77 \%$, total asam $1,344 \mathrm{mg} / \mathrm{g}, \mathrm{pH}$ 3,45 . Sementara uji organoleptiknya menunjukkan bahwa perlakuan dari $35 \%$ mangga $+25 \%$ rosella dan gula $40 \%$ mayoritas disukai oleh panelis. Hal yang sama juga dilaporkan oleh Ref. [7] fruit leather dari buah mangga dengan penambahan gula sebesar $30 \%$ merupakan perlakuan terbaik dengan kadar air sebesar $13,60 \%$, total asam sebesar $1,5 \mathrm{mg} / \mathrm{g}$, pH 5,15, dan uji organoleptik warna $(3,68)$, aroma $(3,36)$, rasa $(3,08$ dan tekstur $(4.00)$.

Berdasarkan penelitian terdahulu mengenai pembuatan fruit leather, maka penelitian ini mencoba membuat fruit leather menggunakan bahan buah kundur dengan kombinasi buah nanas. Hal ini dilakukan karena pemanfaatannya masih sedikit, sementara khasiatnya bagi kesehatan manusia sangat tinggi. Penelitian ini dilakukan untuk mengetahui pengaruh perbandingan buah kundur dan nanas, pengaruh konsentrasi gula, dan pengaruh interaksi antara rasio buah kundur dan nanas serta konsentrasi gula terhadap kualitas fruit leather yang dihasilkan.

\section{Metode Penelitian}

Penelitian ini dilakukan di Laboratorium Analisis Hasil Pertanian dan Laboratorium Organoleptik, Fakultas Teknologi Pertanian, Universitas Serambi Mekkah, Banda Aceh. Penelitian ini dilaksanakan dari tanggal 25 Maret sampai 10 Juli tahun 2019.

Rancangan percobaan yang digunakan adalah Rancangan Acak Lengkap (RAL) 2 faktorial dengan 3 kali ulangan (perbandingan jumlah konsentrasi kundur, nanas, dan gula) dengan susunan kombinasi pada Tabel 1.

Tabel 1. Rancangan percobaan

\begin{tabular}{cccc}
\hline \multirow{2}{*}{ Konsentrasi Kundur dan Nanas $(\mathrm{K})$} & 20 gram & Konsentrasi gula $(\mathrm{G})$ & \\
& $\mathrm{K}_{1} \mathrm{G}_{1}$ & $\mathrm{~K}_{1} \mathrm{G}_{2}$ & 40 gram \\
\hline $80: 20 \%$ & $\mathrm{~K}_{2} \mathrm{G}_{1}$ & $\mathrm{~K}_{2} \mathrm{G}_{2}$ & $\mathrm{~K}_{1} \mathrm{G}_{3}$ \\
$70: 30 \%$ & $\mathrm{~K}_{3} \mathrm{G}_{1}$ & $\mathrm{~K}_{3} \mathrm{G}_{2}$ & $\mathrm{~K}_{2} \mathrm{G}_{3}$ \\
$60: 40 \%$ & & & $\mathrm{~K}_{3} \mathrm{G}_{3}$ \\
\hline
\end{tabular}

\section{Analisis Data}

Data hasil penelitian dianalisis dengan ANOVA (Analysis of Variance). Model linear untuk tiap pengamatan mengacu pada Ref. [8].

Ket:

Yijk : Hasil pengamatan dari faktor konsenterasi kundur dan nanas (K) pada taraf ke-i dan faktor konsentrasi gula $(\mathrm{G})$ pada jarak ke-j dan ulangan ke-k

$\mu \quad$ : Efek nilai tengah

$\mathrm{Ki} \quad$ : Efek dari faktor konsentrasi kundur dan nanas $(\mathrm{K})$ pada taraf ke-i

$\mathrm{Gj} \quad$ : Efek dari faktor konsentrasi gula $(\mathrm{G})$ pada taraf ke-j 
(KG)ij : Efek dari faktor konsentrasi kundur dan nanas (K) pada taraf ke-i dengan faktor konsentrasi gula (G) pada taraf ke-j

€ijk : Efek galat dari faktor konsentrasi kundur dan nanas $(\mathrm{K})$ pada taraf ke-i dan faktor konsentrasi gula $(\mathrm{G})$ pada taraf ke-j dengan ulangan ke-k

\section{Pembuatan bubur buah}

Dilakukan sortasi atau pemilihan buah kundur yang tua dan kulitnya sudah dipenuhi oleh lapisan lilin putih. Buah kundur dikupas kulitnya menggunakan pisau, lalu dicuci pada air mengalir. Buah kundur dipotong menjadi bagian yang lebih kecil agar mudah saat dihancurkan. Potongan kecil tersebut dikukus dalam panci selama \pm 10 menit. Kemudian dihancurkan menggunakan blender untuk menghasilkan bubur buah kundur.

Buah nanas disortasi dan dipilih yaitu buah nanas yang berwarna hijau agak kekuningan dan yang beraroma kuat. Lalu buah dikupas menggunakan pisau dan dicuci pada air yang mengalir. Kemudian nanas dipotong menjadi bagian yang lebih kecil dan dihancurkan sampai menjadi bubur menggunakan blender.

\section{Pembuatan fruit leather [6]}

Dicampur daging buah kundur dan nanas sesuai dengan Tabel 1 yaitu $\mathrm{K}_{1}$ : kundur $80 \%$ + nanas 20 $\%, \mathrm{~K}_{2}$ : kundur $70 \%+$ nanas $30 \%, \mathrm{~K}_{3}$ : kundur $60 \%+$ nanas $40 \%$. Bubur daging buah yang telah di blender lalu dicampurkan dengan konsentrasi gula sesuai perlakuan $20 \%, 30 \%$, 40\%, dan ditambahkan CMC $1 \%$, serta asam sitrat $0,2 \%$. Campuran bubur buah dipanaskan pada suhu $80^{\circ} \mathrm{C}$ selama 2 menit. Lalu, loyang aluminium ukuran $15 \times 30 \times 0,3 \mathrm{~cm}$ dilapisi dengan plastik wrap. Semua adonan yang telah dicampur dimasukkan ke dalam loyang dan dimasukkan ke dalam oven pada suhu $60^{\circ} \mathrm{C}$ dengan lama pengeringan 8 jam untuk proses pengurangan kadar air. Kemudian diteruskan ketahap pemotongan dan pengemasan untuk pengujian hasil produk. Analisis pada fruit leather kundur nanas yang dihasilkan yaitu analisis kadar air [9] dan kadar serat kasar [10]) dan uji organoleptik (uji hedonik) [11].

\section{Hasil dan Pembahasan \\ Kadar Air}

Kadar air berkisar antara 8,15-9,19\%, dengan rata-rata 8,97\%. Kadar air tertinggi diperoleh pada perbandingan kundur dan nanas 70:30\% dan konsentrasi gula 30\% $\left(\mathrm{K}_{2} \mathrm{G}_{2}\right)$ sebesar 9,19\%, sedangkan kadar air terendah diperoleh pada perbandingan kundur dan nanas 80:20\% dan konsentrasi gula 30\% $\left(\mathrm{K}_{1} \mathrm{G}_{2}\right)$ sebesar 8,15\%. Hasil analisa kadar air terdapat pada Tabel 2.

Tabel 2. Kadar air fruit leather kundur nanas

\begin{tabular}{crrr}
\hline \multirow{2}{*}{ Perbandingan kundur dan nanas $(\mathrm{K})$} & \multicolumn{3}{c}{ Konsentrasi gula $(\mathrm{G})$} \\
& $\mathrm{G}_{1}=20 \%$ & $\mathrm{G}_{2}=30 \%$ & $\mathrm{G}_{3}=40 \%$ \\
\hline $\mathrm{K}_{1}=80: 20 \%$ & 9,05 & 8,15 & 8,86 \\
$\mathrm{~K}_{2}=70: 30 \%$ & 9,00 & 9,19 & 9,18 \\
$\mathrm{~K}_{3}=60: 40 \%$ & 9,17 & 8,96 & 9,12 \\
\hline
\end{tabular}

Kadar air juga salah satu karakteristik yang sangat penting pada bahan pangan, karena air dapat mempengaruhi penampakan, tekstur, dan cita rasa pada bahan pangan serta ikut menentukan kesegaran dan daya awet bahan pangan tersebut, kadar air yang tinggi mengakibatkan mudahnya bakteri, kapang, dan khamir untuk berkembang biak, sehingga akan terjadi perubahan pada bahan pangan [9]. Pengaruh interaksi perbandingan kundur dan nanas dan konsentrasi gula dapat dilihat pada Gambar 1.

Gambar 1 menunjukkan bahwa semakin banyak buah nanas yang ditambahkan, maka kadar air akan mengalami peningkatan. Adanya perbedaan kadar air yang terikat pada fruit leather kundur nanas yang dihasilkan disebabkan oleh perbedaan kandungan air pada bahan baku yang digunakan seperti buah kundur sebesar 93,7\% [12] dan buah nanas sebesar 86,10\% [13]. Perbedaan perbandingan buah kundur dan nanas menghasilkan kadar air yang berbeda. Penambahan gula pada pembuatan fruit leather berkontribusi pada kekentalan bubur yang dihasilkan. Molekul hidrofilik dari karbohidrat mampu mengikat air dalam bubur buah sehingga menyebabkan berkurangnya stabilitas daya alir dari fruit leather. 


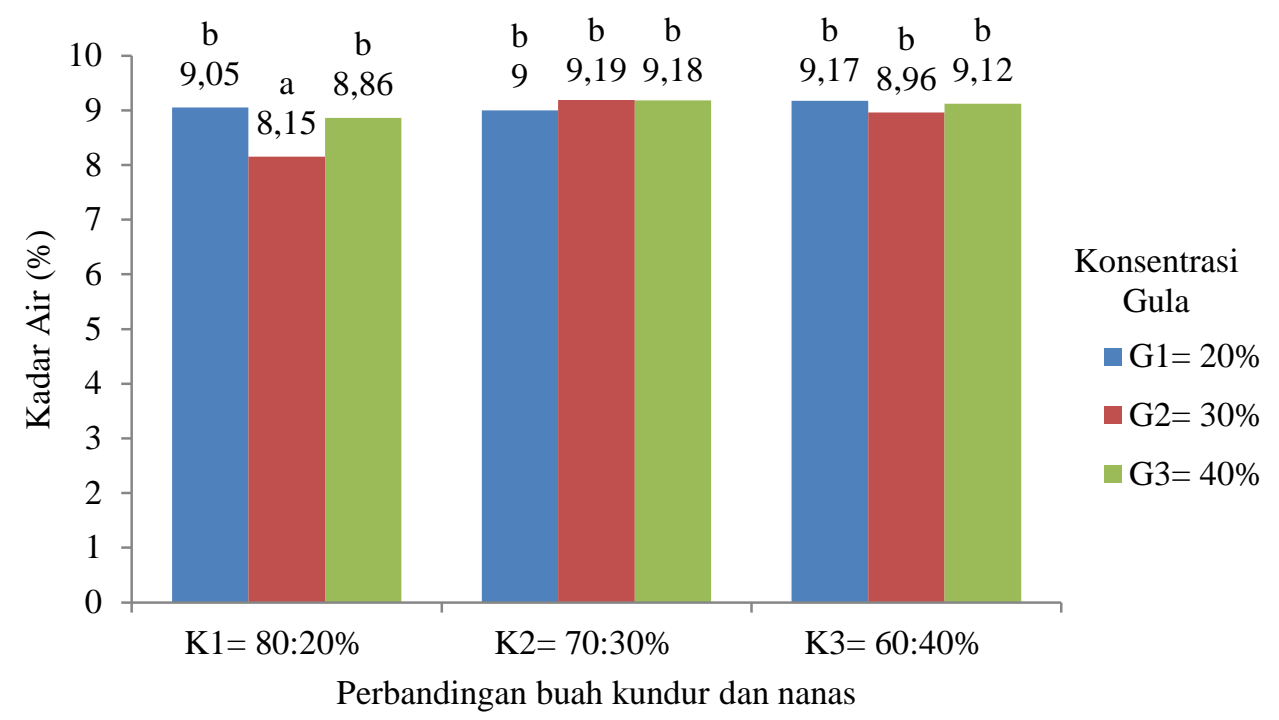

Gambar 1. Pengaruh interaksi perbandingan kundur dan nanas dan konsentrasi gula terhadap kadar air fruit leather $\mathrm{BNT}_{0.01}=0,50$ dan $\mathrm{KK}=2,11 \%$.

Penambahan gula di atas $40 \%$ dari bahan berkontribusi pada kenaikan kadar air pada fruit leather karena bahan mengikat lebih banyak air. Berdasarkan analisis kadar air fruit leather sudah memenuhi syarat mutu fruit leather sebagai bahan makanan pada semua perlakuan. SNI kadar air fruit leather maksimal 25\%, sedangkan persentase parameter kadar air yang dihasilkan memiliki kadar air rata-rata $8,97 \%$. Kadar air dari hasil penelitian ini lebih rendah daripada kadar air pada fruit leather dari nangka yang berkisar $9,82 \%$ [14]

\section{Kadar serat}

Kadar serat fruit leather kundur nanas berada pada 0,279 - 1,974\%, dengan rata-rata 1,197\%. Kadar serat tertinggi diperoleh pada perbandingan kundur dan nanas 80:20\% dan konsentrasi gula 20\% $\left(\mathrm{K}_{1} \mathrm{G}_{1}\right)$ sebesar $1,974 \%$, sedangkan kadar serat terendah diperoleh pada perbandingan kundur dan nanas 70:30\% dan konsentrasi gula $40 \%\left(\mathrm{~K}_{2} \mathrm{G}_{3}\right)$ sebesar 0,279\%. Hasil analisa kadar serat terlihat pada Tabel 3.

Tabel 3. Kadar serat fruit leather kundur nanas

\begin{tabular}{crrr}
\hline Perbandingan kundur dan nanas $(\mathrm{K})$ & \multicolumn{3}{c}{ Konsentrasi gula $(\mathrm{G})$} \\
& $\mathrm{G}_{1}=20 \%$ & $\mathrm{G}_{2}=30 \%$ & $\mathrm{G}_{3}=40 \%$ \\
\hline $\mathrm{K}_{1}=80: 20 \%$ & 1,974 & 1,882 & 1,809 \\
$\mathrm{~K}_{2}=70: 30 \%$ & 0,564 & 0,297 & 0,279 \\
$\mathrm{~K}_{3}=60: 40 \%$ & 1,504 & 1,426 & 1,041 \\
\hline
\end{tabular}

Serat kasar adalah suatu residu tidak larut yang dihasilkan dari reaksi hidrolisis asam dan hidrolisis basa yang berupa selulosa murni dan lignin tidak larut. Kualitas serat pangan ditentukan oleh komponen serat makanan yang dikandungnya mencakup komponen yang larut dan komponen yang tidak larut. Komponen dari serat kasar ini kurang mempunyai nilai gizi, akan tetapi serat ini sangat penting untuk proses memudahkan dalam pencernaan di dalam tubuh agar proses pencernaan tersebut lancar [10].

Hasil analisa sidik ragam menunjukkan bahwa perbandingan kundur dan nanas dan konsentrasi gula serta interaksi kedua perlakuan berpengaruh sangat nyata $(\mathrm{P} \leq 0.01)$ terhadap kadar serat fruit leather kundur nanas. Pengaruh interaksi perbandingan kundur dan nanas dan konsentrasi gula dapat dilihat pada Gambar 2.

Gambar 2 menunjukkan bahwa semakin banyak penambahan gula dan buah kundur maka kadar serat yang dihasilkan cenderung menurun. Besarnya kadar serat kasar pada fruit leather kundur nanas ini sangat ditentukan oleh kadar serat yang terkandung dalam buah kundur dan buah nanas yang digunakan. Kadar serat buah kundur sekitar 0,36\% [12] dan buah nanas sekitar 1.6\% [13]. Peningkatan kadar serat kasar disebabkan oleh penambahan gula pasir, karena gula pasir mengandung karbohidrat dan polisakarida serta serat yang bersifat soluble dalam air, sehingga dengan penambahan gula mengakibatkan kadar serat kasar pada fruit leather kundur dan nanas mengalami kenaikan. 


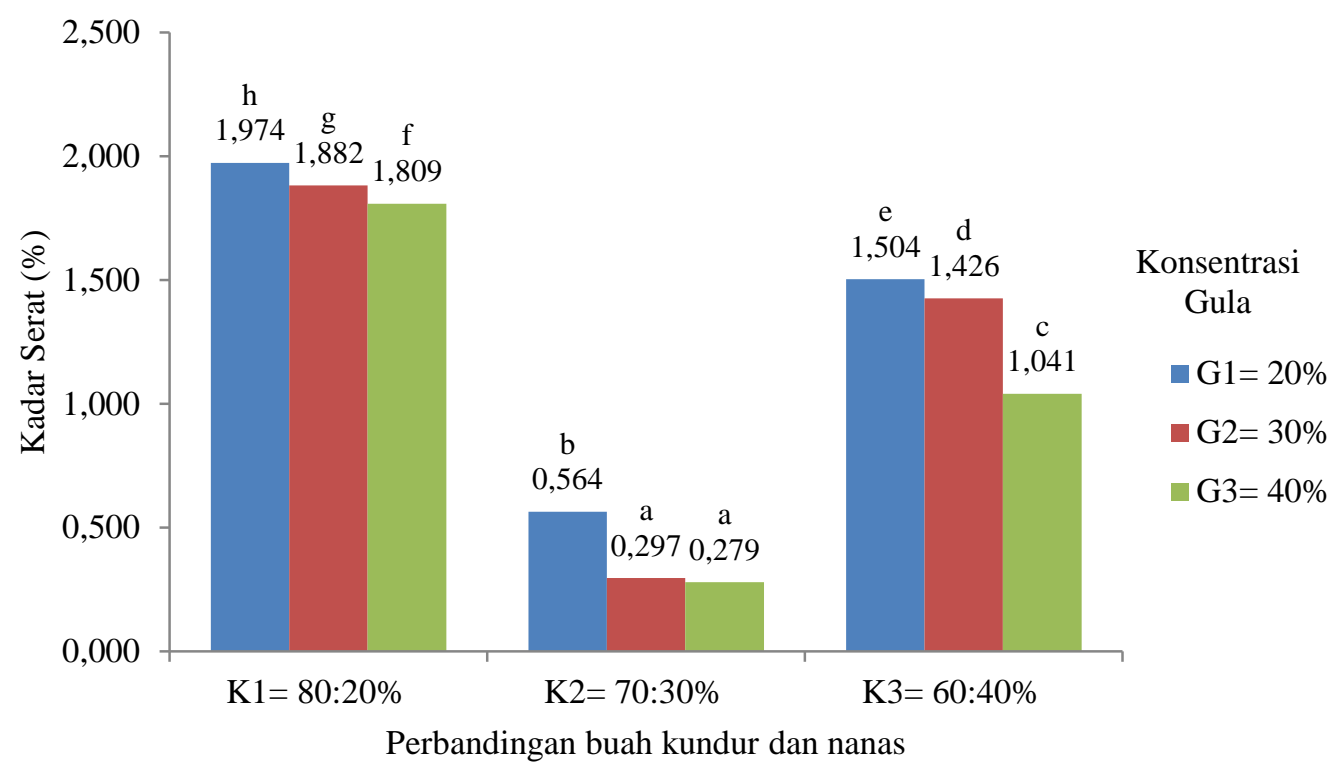

Gambar 2. Pengaruh interaksi perbandingan kundur dan nanas dan konsentrasi gula terhadap kadar serat fruit leather $\mathrm{BNT}_{0.01}=0,02$ dan $\mathrm{KK}=0,50 \%$.

Hal ini sesuai dengan [15] yang menyatakan serat yang larut dalam air cenderung bercampur dengan air membentuk jaringan gel (seperti agar) atau jaringan yang pekat, sehingga semakin banyak konsentrasi gula pada fruit leather maka kadar serat kasar pun mengalami kenaikan. Kadar serat yang dihasilkan pada penelitian ini lebih rendah dari kadar serat dari fruit leather buah sirsak dan melon [16] berkisar 1,91\% dan fruit leather nanas dan wortel berkisar 1,9 sampai 5,7\% [17].

Tekstur

Uji organoleptik tekstur fruit leather pada berbagai perlakuan berkisar antara 3,78 (suka) - 4,09 (suka) dengan rata-rata yaitu 3,88 (suka). Nilai organoleptik tekstur tertinggi terdapat pada perbandingan kundur dan nanas 60:40\% dan konsentrasi gula 30\% $\left(\mathrm{K}_{3} \mathrm{G}_{2}\right)$ sebesar 4,09 (suka) dan perlakuan terendah diperoleh pada perbandingan kundur dan nanas 80:20\% dan konsentrasi gula $40 \%\left(\mathrm{~K}_{1} \mathrm{G}_{3}\right)$ sebesar 3.78 (suka). Hasil uji organoleptik tekstur fruit leather terdapat pada Tabel 4.

Tabel 4. Uji organoleptik tekstur fruit leather kundur nanas

\begin{tabular}{crrr}
\hline Perbandingan kundur dan nanas $(\mathrm{K})$ & $\mathrm{G}_{1}=20 \%$ & $\mathrm{G}_{2}=30 \%$ & $\mathrm{G}_{3}=40 \%$ \\
\hline $\mathrm{K}_{1}=80: 20 \%$ & 3,91 & 3,80 & 3,78 \\
$\mathrm{~K}_{2}=70: 30 \%$ & 3,80 & 3,91 & 3,82 \\
$\mathrm{~K}_{3}=60: 40 \%$ & 3,94 & 4,09 & 3,87 \\
\hline
\end{tabular}

Komposisi bubur kundur yang lebih besar diperoleh fruit leather yang memiliki tekstur yang lebih lembut. Kondisi dimana bubur buah nanas yang lebih besar menghasilkan fruit leather dengan tekstur lebih keras. Tekstur fruit leather yang lebih lembut menghasilkan gulungan fruit leather yang lebih baik. Perlakuan pengeringan menyebabkan serat pada buah akan mengikat air sehingga tekstur fruit leather yang dihasilkan agak sedikit keras.

\section{Rasa}

Uji organoleptik rasa fruit leather pada perbagai perlakuan berkisar antara 3,80 (suka)-4,18 (suka) dengan rata-rata yaitu 3,92 (suka). Uji organoleptik rasa terendah terdapat pada perbandingan kundur dan nanas 80:20\% dan konsentrasi gula 40\% $\left(\mathrm{K}_{1} \mathrm{G}_{3}\right)$ sebesar 3,80 (suka) dan perlakuan tertinggi diperoleh pada perbandingan kundur dan nanas 60:40\% dan konsentrasi gula $20 \%\left(\mathrm{~K}_{3} \mathrm{G}_{1}\right)$ sebesar 4.18 (suka). Hasil analisa uji organoleptik rasa fruit leather terlihat pada Tabel 5.

Hasil analisis sidik ragam menunjukkan perbandingan kundur dan nanas dan konsentrasi gula serta interaksi antara kedua perlakuan berpengaruh tidak nyata $(\mathrm{P}>0.05)$ terhadap uji organoleptik rasa fruit leather. Fruit leather kundur nanas yang dihasilkan memiliki rasa manis yang normal. Penambahan konsentrasi gula pada campuran bubur buah kundur dan nanas meningkatkan kesukaan rasa dari panelis. 
Tabel 5. Uji organoleptik rasa fruit leather kundur nanas

\begin{tabular}{crrr}
\hline \multirow{2}{*}{ Perbandingan kundur dan nanas $(\mathrm{K})$} & \multicolumn{3}{c}{ Konsentrasi gula $(\mathrm{G})$} \\
$\mathrm{G}_{2}=30 \%$ & $\mathrm{G}_{3}=40 \%$ \\
\hline $\mathrm{K}_{1}=80: 20 \%$ & 3,84 & 3,91 & 3,80 \\
$\mathrm{~K}_{2}=70: 30 \%$ & 3,82 & 3,89 & 3,93 \\
$\mathrm{~K}_{3}=60: 40 \%$ & 4,18 & 3,96 & 3,91 \\
\hline
\end{tabular}

Rasa manis yang dimiliki fruit leather kundur dan nanas ini masih berada pada tingkat normal, dimana pada penambahan gula tertinggi tidak menimbulkan rasa manis yang over pada fruit leather kundur dan nanas tersebut.

Rasa asam yang timbul dari fruit leather dihasilkan dari buah nanas yang memiliki rasa yang lebih dominan dibandingkan buah kundur yang rasanya langu. Perpaduan fruit leather kundur nanas memberikan keseimbangan antara rasa segar dan rasa manis yang ditimbulkan. Rasa fruit leather dipengaruhi oleh gula, sukrosa dan komponen asam pada buah serta suhu pengeringan yang dilakukan. Perbandingan bubur buah kundur dan nanas yang berbeda akan menimbulkan rasa yang berbeda pula. Ketika bubur nanas yang lebih banyak ditambahkan maka rasa fruit leather nya lebih manis.

\section{Warna}

Uji organoleptik warna fruit leather pada berbagai perlakuan berkisar antara 3,73 (suka) - 4,11 (suka) dengan rata-rata yaitu 3,87 (suka). Nilai organoleptik warna tertinggi terdapat pada perbandingan kundur dan nanas 60:40\% dan konsentrasi gula 40\% $\left(\mathrm{K}_{3} \mathrm{G}_{3}\right)$ sebesar 4,11 (suka) dan perlakuan terendah diperoleh pada perbandingan kundur dan nanas 80:20\% dan konsentrasi gula $20 \%\left(\mathrm{G}_{1} \mathrm{~L}_{1}\right)$ sebesar 3.62 (suka). Hasil analisa uji organoleptik warna dapat dilihat pada Tabel 6.

Tabel 6. Uji organoleptik warna fruit leather kundur nanas

\begin{tabular}{cccc}
\hline \multirow{2}{*}{ Perbandingan kundur dan nanas $(\mathrm{K})$} & $\mathrm{G}_{1}=20 \%$ & Konsentrasi gula $(\mathrm{G})$ & $\mathrm{G}_{2}=30 \%$ \\
\hline $\mathrm{K}_{1}=80: 20 \%$ & 3,62 & 3,71 & $\mathrm{G}_{3}=40 \%$ \\
$\mathrm{~K}_{2}=70: 30 \%$ & 3,85 & 3,89 & 3,73 \\
$\mathrm{~K}_{3}=60: 40 \%$ & 3,98 & 4,05 & 3,93 \\
\hline
\end{tabular}

Menurut [20] warna merupakan sifat produk pangan yang dapat dilihat sebagai sifat fisik (objektif) dan sifat organoleptik (subjektif). Warna produk fruit leather kundur nanas dalam penelitian ini ditentukan dengan uji organoleptik atau subjektif dengan menggunakan indera penglihatan manusia. Hasil analisis sidik ragam menunjukkan bahwa perbandingan kundur dan nanas dan konsentrasi gula berpengaruh sangat nyata $(\mathrm{P}<0.01)$, sedangkan interaksi antara kedua perlakuan berpengaruh tidak nyata $(\mathrm{P} \geq 0.05)$ terhadap uji organoleptik warna fruit leather yang dihasilkan. Pengaruh perbandingan kundur dan nanas dan konsentrasi gula terlihat pada Gambar 3 dan Gambar 4.

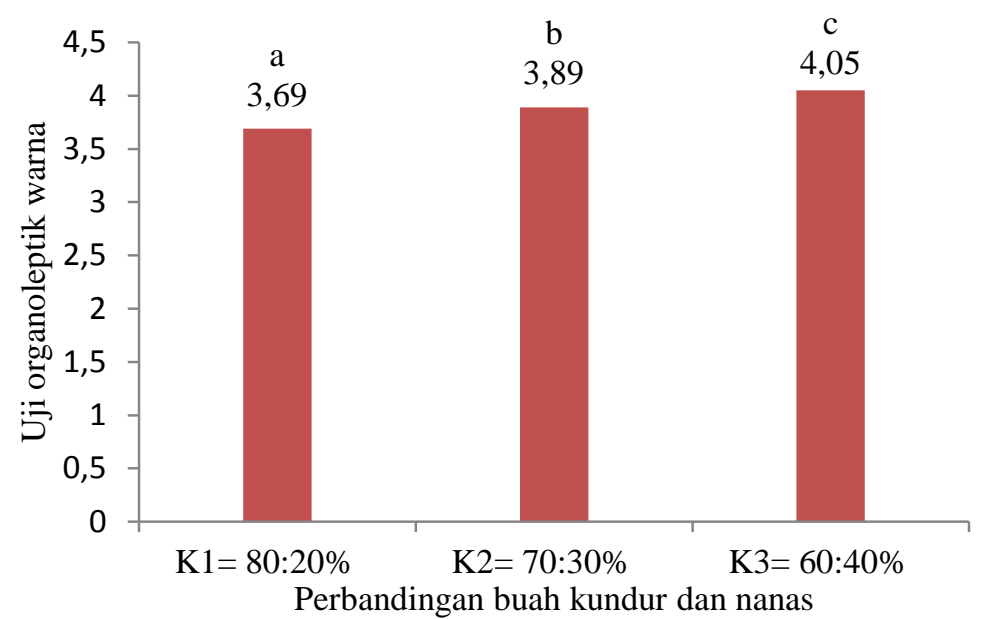

Gambar 4. Pengaruh perbandingan buah kundur dan nanas terhadap uji organoleptik warna fruit leather $\mathrm{BNT}_{0.01}=0,17$ dan $\mathrm{KK}=1,66 \%$ 
Gambar 4 menunjukkan bahwa semakin tinggi konsentrasi buah kundur yang ditambahkan maka panelis semakin menyukai warna fruit leather kundur nanas yang dihasilkan yaitu sedikit kecokelatan. Saat pencampuran bubur daging buah kundur dan buah nanas adonan berwarna kuning muda. Warna kecokelatan timbul dari hasil reaksi karamelisasi dari gula yang terkandung pada bubur daging buah. Pada suhu pengeringan yang dijaga tetap, warna fruit leather kundur nanas tidak menunjukkan perubahan yang nyata. Warna bahan pangan merupakan hasil dari pantulan, sebaran, serapan atau terusan dari sinar yang tampak yang dihasilkan oleh fruit leather kundur nanas.

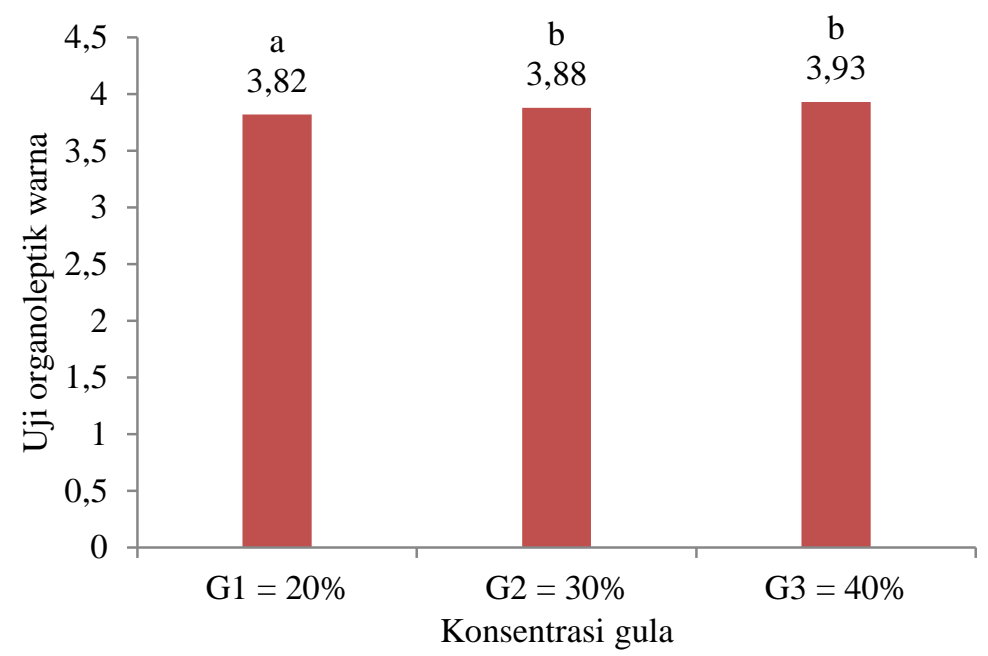

Gambar 5. Pengaruh konsentrasi gula terhadap uji organoleptik warna fruit leather $\mathrm{BNT}_{0.01}=0,17$ dan $\mathrm{KK}=1,66 \%$.

Gambar 5 memperlihatkan bahwa semakin tinggi konsentrasi gula yang ditambahkan maka panelis semakin menyukai warna fruit leather yang dihasilkan. Hal ini dapat disebabkan oleh fungsi gula pasir yang mempengaruhi warna fruit leather. Hal ini diduga karena adanya hidrolisis sukrosa karena pemanasan.

\section{Aroma}

Uji organoleptik aroma fruit leather pada berbagai perlakuan berkisar antara 3,58 (suka) - 4,00 (suka) dengan rata-rata yaitu 3,79 (suka). Nilai organoleptik aroma tertinggi terdapat pada perbandingan kundur dan nanas 80:20\% dan konsentrasi gula 40\% $\left(\mathrm{K}_{1} \mathrm{G}_{3}\right)$ sebesar 4,00 (suka) dan perlakuan terendah diperoleh pada perbandingan kundur dan nanas 80:20\% dan konsentrasi gula 30\% $\left(\mathrm{K}_{1} \mathrm{LG}_{2}\right)$ sebesar 3.58 (suka). Hasil analisa uji organoleptik aroma tampak pada Tabel 7.

Tabel 7. Uji organoleptik aroma fruit leather kundur nanas

\begin{tabular}{crrr}
\hline Perbandingan kundur dan nanas $(\mathrm{K})$ & $\mathrm{G}_{1}=20 \%$ & $\begin{array}{c}\text { Konsentrasi gula }(\mathrm{G}) \\
\mathrm{G}_{2}=30 \%\end{array}$ & $\mathrm{G}_{3}=40 \%$ \\
\hline $\mathrm{K}_{1}=80: 20 \%$ & 3,76 & 3,58 & 4,00 \\
$\mathrm{~K}_{2}=70: 30 \%$ & 3,76 & 3,91 & 3,76 \\
$\mathrm{~K}_{3}=60: 40 \%$ & 3,67 & 3,87 & 3,84 \\
\hline
\end{tabular}

Hasil analisis sidik ragam menunjukkan bahwa perbandingan kundur dan nanas dan konsentrasi gula serta interaksi antara kedua perlakuan berpengaruh tidak nyata $(\mathrm{P}>0.05)$ terhadap uji organoleptik aroma fruit leather. Aroma fruit leather yang dihasilkan cenderung lebih beraroma gula (karamel). Hal ini disebabkan karena penambahan gula berperan dalam pembentukan rasa, flavor dan penampakan yang baik pada fruit leather. Gula memiliki kemampuan dalam mengikat komponen dalam bahan pangan salah satunya berupa flavor, sehingga komponen volatil dari buah kundur dan nanas tidak sepenuhnya menguap pada waktu pemanasan. Aroma fruit leather kundur nanas sangat didominasi dengan aroma buah nanas. Buah nanas memiliki aroma asam manis dari senyawa volatil yang khas dan kuat yang terkandung di dalamnya. Penambahan buah nanas menutupi aroma langu dari buah kundur.

\section{Kesimpulan}

Perlakuan terbaik dalam penelitian ini terdapat pada perbandingan konsentrasi buah kundur dan nanas 80:20\% dan konsentrasi gula $30 \%\left(\mathrm{~K}_{1} \mathrm{G}_{2}\right)$ yang menghasilkan fruit leather dengan mutu yang baik 
dengan kadar air 8,15\%, kadar serat 1,882, uji organoleptik tektur 3,80 (suka), warna 3,71 (suka), aroma 3,58 (suka) dan rasa 3,91 (suka).

\section{Referensi}

[1] Al-Snafi, A.E, "The pharmocological importance of Benincasa hispida," A review. International Journal of pharma Sciences and Research, 4(12): 165-170, 2013.

[2] Grubben, G.J.H, Vegetable.USA: National Horticultural Research Institute. 2004.

[3] Sanhez R. M., H. P. Bermed Andrade, C. P. V. Real, "Incidence of hydrocolloid type on quality parameters in mango leathers (Mangifera indica L.) Yulima variety," Food Science and Technology. 38 (1): 109-115, 2018.

[4] Zhaki M., N. Harun, dan F. Hamzah, "Penambahan Berbagai Konsentrasi Karagenan terhadap Karakteristik Fruit Leather Pepaya," JOM UR. Vol. 5: 1-14, 2018.

[5] Asben, A, "Peningkatan Kadar Iodium dan Serat Pangan dalam Pembuatan Fruit leathers Nanas (Ananas comosus L. Merr) dengan Penambahan Rumput Laut," (Skripsi), Fakultas Pertanian. Padang: Universitas Andalas, 2007.

[6] Safitri, A. A. "Studi pembuatan fruit leather mangga - rosella," Skripsi, Jurusan Teknologi Pertanian. Fakultas Pertanian. Makasar: Universitas Hasanuddin, 2012.

[7] Rosalina Y., L. Susanti dan T. Sulasmi, Studi Pengolahan Fruit Leather Mangga Varietas Bengkulu (Mangifera indica L.)," Jurnal Agroindustri. 3(2): 124 - 131, 2013.

[8] Sugiarto Sugandi E, 1994, Rancangan Percobaan Teori Dan Aplikasi. Yogyakarta : Andi Offset.

[9] Alang, S, Penentuan Kadar Air dan Kadar Abu. Laboratorium Kimia Analisa dan Pengawasan Mutu Pangan. Makasar. Universitas Hasanuddin, 2012.

[10] AOAC, Official Methods of Analysis. Association of Official Analytical Chemists. Washington: Benjamin Franklin Station, 2005.

[11] Soekarto, S, Penilaian Organoleptik untuk Industri Pangan dan Hasil Pertanian. Jakarta: Bharata Karya Aksara, 2002.

[12] Zaini, N, "Kundur (Benincasa hispida): A Potential Source for Valuable Nutrients and Functional Foods," Food Research International, 44 (2011) 2368-2376, 2011.

[13] USDA (2014), "Nutritional value of pineapples raw," http:ndb.nal.usda.gov.

[14] Praseptiangga, D., T. P. Aviany, N. H. R. Parnanto, "Pengaruh Penambahan Gum Arab terhadap Karakteristik Fisikokimia dan Sensoris Fruit Leather Nangka (Artocarpus heterophyllus)". Jurnal Teknologi Hasil Pertanian.9 (1): 71-83, 2016.

[15] Wirjatmadi, B., M. Adrianti dan S Purwati, "Pemanfaatan Rumput Laut (Eucheuma cottonii) dalam Meningkatkan Kandungan Serat dan Yodium Tepung Terigu dalam Pembuatan Mie Basah," Jurnal Penelitian Medika Eksakta, 13(1): 11-17, 2002.

[16] Risti, A.P., N. Herawati. "Pembuatan Fruit Leather dari Campuran Buah Sirsak (Annoma muricata L.) dan Buah Melon (Cucumis melo L.)", JOM Fakultas Pertanian, 4(2): 1-15, 2017.

[17] Sidi, N.C., E. Widowati, A. Nursiwi, "Pengaruh Penambahan Karagenan pada Karakteristik Fisikokimia dan Sensoris Fruit Leather Nanas (Ananas Comosus L. Merr.) dan Wortel (Daucus Carota)", Jurnal Aplikasi Teknologi Pangan, 3 (4):122-127, 2014. 